Hydrogeology Journal

https://doi.org/10.1007/s10040-020-02184-0

\title{
REPORT
}

This is a post-peer-review, pre-copyedit version of an article published in Hydrogeology Journal. The final authenticated version is available online at: https://link.springer.com/article/10.1007/s10040-020-02184-0

\section{Evolution and assessment of a nitrate vulnerable zone over 20 years: Gallocanta groundwater body (Spain)}

\author{
J. M. Orellana-Macías ${ }^{1,2} \cdot$ D. Merchán ${ }^{3} \cdot$ J. Causapé $^{1}$ \\ Received: 7 October 2019 / Accepted: 10 May 2020 \\ (C) Springer-Verlag GmbH Germany, part of Springer Nature 2020
}

\begin{abstract}
Nitrate pollution from agricultural sources is one of the biggest issues facing groundwater management in the European Union (EU). During the last three decades, tens of nitrate vulnerable zones (NVZ) have been designated across the EU, aiming to make the problem more manageable. The Gallocanta Groundwater Body in NE Spain was declared as an NVZ in 1997, and after more than 20 years, significant improvements in water quality were expected to be observed. In the present study, the spatiotemporal trend of nitrate concentration within the Gallocanta NVZ in the last 38 years was assessed, and the effectiveness of the NVZ implementation was tested. Data from the official Ebro Basin Confederation monitoring network from 1980 to 2018 were used, and the results showed an increasing but fluctuating trend in nitrate concentration since 1980. Although a slight improvement was
\end{abstract}

detected after the NVZ designation in 1997, the low rate of improvement would take decades to reach desirable levels in most of

the area. The lack of update and control of action programmes, the inappropriate NVZ delimitation, and the influence of natural factors seem to be the reasons for the failure of the nitrate reduction measures. Currently, nitrate pollution and groundwater management are a matter of concern for the EU, so given the recurring problems in water supply in the area and the nonfulfillment of the goal of good quality status, more demanding measures are needed to be implemented in the short term.

\section{Keywords Contamination $\cdot$ Endorreism $\cdot$ Groundwater management $\cdot$ Nitrate $\cdot$ Spain \\ Introduction}

Nitrate pollution in surface water and groundwater has been related to human activities in many countries across the world

Electronic supplementary material The online version of this article (https://doi.org/10.1007/s10040-020-02184-0) contains supplementary material, which is available to authorized users.

J. M. Orellana-Macías

jm.orellana@igme.es

D. Merchán

eremad@hotmail.com

J. Causapé

j.causape@igme.es

1 Geological Survey of Spain-IGME, C/ Manuel Lasala 44 9B, 50006 Zaragoza, Spain

2 Department of Earth Sciences, University of Zaragoza, C/ Pedro Cerbuna 12, 50009 Zaragoza, Spain

3 Department of Engineering, IS-FOOD Institute (Innovation \& Sustainable Development in Food Chain), Public University of Navarre, Campus de Arrosadía, 31006 Pamplona, Spain (e.g. Kyllmar et al. 2005; Liu et al. 2005; Matzeu et al. 2017; Serio et al. 2018). Nitrate $\left(\mathrm{NO}_{3}{ }^{-}\right)$concentrations found naturally in groundwater are low, but there are increases in concentration, mainly associated with anthropogenic factors such as agricultural fertilizer application, animal farming, and industrial and urban wastewater discharges (Liu et al. 2005; Dubrovsky et al. 2010). Whereas animal farming and industrial or urban discharges are relatively easy to mitigate, since they usually originate from point sources, $\mathrm{NO}_{3}{ }^{-}$leaching from agricultural sources is considered a nonpoint source (Sutton et al. 2011) and is harder to control and prevent. $\mathrm{NO}_{3}{ }^{-}$arising from diffuse agricultural sources has been recognized as one of the main causes of groundwater degradation (Sutton et al. 2011; Wick et al. 2012; Zhang et al. 2019).

The higher $\mathrm{NO}_{3}{ }^{-}$requirements of crops and the rising surface area of cultivated land, along with pressure to produce food at affordable prices and the ease of application of nitrogen fertilizers, have led to an increase in $\mathrm{NO}_{3}{ }^{-}$use during the last several decades (Di and Cameron 2002; Worrall et al. 2009; Sutton et al. 2011; Basso et al. 2015). Over application of nitrogen fertilizers takes place both in irrigated and rainfed areas, and the main consequence is the leaching of surplus 
nitrogen from agricultural land to aquifers and surface water due to the high mobility of $\mathrm{NO}_{3}{ }^{-}$(Billen 2013; Merchán et al. 2015; Serio et al. 2018). The impact of leaching varies considerably with climate conditions, type of soil, lithology, depth of the vadose zone, irrigation/fertilizer management practices, land use, depth to the water table, and topography, among others (Di and Cameron 2002; Quemada et al. 2013; Arauzo 2017).

High levels of $\mathrm{NO}_{3}{ }^{-}$have a negative impact, e.g. the eutrophication of water bodies and the development of methemoglobinemia in infants (USEPA 2007). As a consequence, the quality of surface water and groundwater for human use has been protected by several countries. In the USA and Canada, the $\mathrm{NO}_{3}{ }^{-}$limit in drinking water is $45 \mathrm{mg} \mathrm{L}^{-1}$ (USEPA 1996; Health Canada 2013), whereas the recommendation of the World Health Organization is a threshold of $50 \mathrm{mg} \mathrm{L}^{-1}$ (WHO 2011). In the European Union (EU), the Nitrates Directive 91/676/EEC aims to protect water bodies against pollution caused by nitrate from agricultural sources, and set the threshold at $50 \mathrm{mg} \mathrm{L}^{-1}$ to declare water bodies as affected (EEC 1991). If concentrations are within the range of 25 $50 \mathrm{mg} \mathrm{L}^{-1}$, the water body can be considered at risk and protection measures should be taken (BOE 1996). The Nitrates Directive also established that the European states should identify and designate protected areas based on $\mathrm{NO}_{3}{ }^{-}$ concentration levels. The so-called nitrate vulnerable zones (NVZ) are defined as areas of land that drain into polluted water or waters at risk of pollution and which contribute to the pollution of those waters (EEC 1991). In these areas, action programmes must be implemented to deal with the pollution. Instead of appointing specific areas, the member states can decide to include all their agricultural territory under action programmes, as has been done in countries such as Austria, Denmark, Germany, Ireland or The Netherlands. In addition, member states are also required to establish codes of good agricultural practice (CPAP) to be implemented by farmers on a voluntary basis, action programmes within NVZs on a compulsory basis, and to carry out control programmes every 4 years.

Despite the important legislative effort, several studies have called into doubt the efficiency of this procedure, due to the significant differences in the way that NVZs are designated in each country, the voluntary basis of the application of the CPAP, and the ambiguous interpretation of the action programmes (e.g. Worrall et al. 2009; Arauzo and MartínezBastida 2015; Richard et al. 2018). The European Commission (EC) itself questions the effectiveness of the NVZ declaration and its action programmes (EC 2010; 2018) since the criteria are not explicit, and in some countries the declared zone is limited to small areas around the monitoring stations, which leads to declaring isolated or fragmented areas that are not a representation of the affected water bodies. According to the reports submitted by the member states to the EC, in 2015 the total area declared as NVZ in Europe increased by $12 \%$ with respect to 2012, reaching $2,175,861 \mathrm{~km}^{2}$, or ca. $61 \%$ of the agricultural land (EC 2018).

Assessment of the efficiency of the NVZ implementation across Europe has been traditionally carried out by the EC, focusing on a country scale. In 2003 and 2009, the International MonNO3 workshops took place focusing on monitoring the effectiveness of the Nitrates Directive action programmes in different countries (Fraters et al. 2005, 2011). In addition, several studies have assessed the effectiveness of $\mathrm{NVZ}$ designation on the improvement of $\mathrm{NO}_{3}{ }^{-}$levels in water bodies at a catchment scale. For instance, Neal et al. (2006), Lord et al. (2007), and Worrall et al. (2009) analysed $\mathrm{NO}_{3}{ }^{-}$ concentration in NVZs linked to surface water bodies in the UK, Rojek et al. (2017) compared $\mathrm{NO}_{3}{ }^{-}$trends in groundwater in NVZs and non-NVZs in Poland, and Arauzo and Valladolid (2011) and Arauzo and Martínez-Bastida (2015) observed a lack of defined criteria when designating NVZs in different catchments in Spain, which resulted in an inappropriate area designation and thus in the failure of the action programmes. On the other hand, others studies have focused on the farmers' and stakeholders' perspectives. Musacchio et al. (2019) analysed $\mathrm{NO}_{3}{ }^{-}$concentration trend in the River Po catchment in Italy and developed a "net-map" of actors in water governance. In Scotland (UK), MacGregor and Warren (2006) questioned whether the measures associated with NVZ were enough to reduce diffuse $\mathrm{NO}_{3}{ }^{-}$pollution; in this case, an improvement in water quality in the long-term associated with NVZ regulations, economic pressures and the role of farmers could be demonstrated (MacGregor and Warren 2015).

Following the Nitrates Directive, in 1997 the Gallocanta Groundwater Body (GGB) was designated as one of the first NVZs in Spain (BOA 1997). The GGB is a particular case due to its relationship with a lagoon of international interest (Ramsar Convention) located in an endorheic catchment. The first NVZ declaration protected $155 \mathrm{~km}^{2}$ surrounding the lagoon and the south part of the groundwater body. In 2008, the NVZ was extended to $208 \mathrm{~km}^{2}$ in the III Action Programme which was continued by the IV and the V Action Programme in 2013 and 2019. Following the Spanish legislation, the new delimitation excluded part of the former NVZ area, due to low concentration levels recorded on that zone. Despite all of this and the long period (20 years) since the NVZ implementation, and despite several action programmes and changes in the extension of the NVZ, an improvement in the $\mathrm{NO}_{3}{ }^{-}$concentration within the GGB should be expected. Thus, this study aimed to analyse the $\mathrm{NO}_{3}{ }^{-}$dynamics in the GGB. The specific objectives were: (1) to understand $\mathrm{NO}_{3}{ }^{-}$ dynamics in the aquifers; (2) to detect and quantify trends in $\mathrm{NO}_{3}{ }^{-}$concentration through the last ca. 38 years, and (3) to test the efficiency of the NVZ protection program and related measures in the long term. 


\section{Methods and materials}

\section{Study site}

The study area encompasses $540 \mathrm{~km}^{2}$, covering the Gallocanta Lagoon catchment, an endorheic basin located in the Autonomous Communities of Aragón and Castilla-La Mancha (north-east Spain). This catchment is within the Gallocanta Hydrogeologic Unit and it is characterized by the different extensions of the surface water and the groundwater catchments (Fig. 1). The latter $\left(223 \mathrm{~km}^{2}\right)$ is almost completely contained within the former.

Topographic elevation in the catchment ranges from $990 \mathrm{~m}$ above sea level (ASL) at the lowest part, where the lagoon is located, up to 1,400 m ASL in the NE (Sierra de Santa Cruz) and SW (Sierra de Menera) boundaries. Some short and ephemeral water courses flow from those mountains to the lagoon when rainfall is high enough. However, the territory has a flat morphology, so that surface-water infiltrates into the aquifers before it can reach the lagoon for most of the time.

The climate in the area is Mediterranean semiarid, with a remarkable continental and altitudinal influence and peak rainfall in spring and fall. Annual rainfall is $391 \pm 112 \mathrm{~mm}$ (average \pm standard deviation), which denotes the high interannual variation typical of Mediterranean climate, and the annual mean temperature is $11.6^{\circ} \mathrm{C}$.

According to the water basin authority, Ebro Hydrographic Confederation (CHE from its Spanish acronym), the GGB is associated with the groundwater catchment. It is a multilayer aquifer system composed of an unconfined detritic Quaternary aquifer surrounding the lagoon, and Mesozoic carbonated aquifers (partially permeable) formed by materials with different hydraulic properties: Utrillas sandy materials, fractured and karstic Cretaceous and Jurassic limestones, and sandy low-permeability Triassic materials. There is a Paleozoic aquifer in the eastern area of the basin, under the Sierra de Santa Cruz layer, with low hydraulic conductivity and is practically unpolluted (CHE 2016). The Quaternary aquifer covers the lowest lands and it is composed of filling materials (quarzitic sand, alluvial fans, glacis and Quaternary lake sediments; CHE 2012). Its hydraulic conductivity is high $\left(0.5 \mathrm{~m} \mathrm{day}^{-1}\right)$ and the thickness ranges between 5 and $20 \mathrm{~m}$. In relation to the Mesozoic aquifers, the Utrillas formation can be considered as an aquitard. Due to its low hydraulic conductivity $\left(0.0001 \mathrm{~m} \mathrm{day}^{-1}\right)$, it partially separates the Cretaceous and the Jurassic aquifers (CHE 2003). On the other hand, the unconfined carbonated Cretaceous aquifer has moderate hydraulic conductivity due to fracturation and karstification (CHE 2016). It has a thickness between 200 and $300 \mathrm{~m}$ and covers the western parts of the basin. Cretaceous outcrops cover large areas in the western, south-western and southern of the study area. The Jurassic aquifer is also extended over the western part of the basin. It can be considered a diffuse-flow carbonated aquifer. Its hydraulic conductivity is high due to fracturation and karstification, and its thickness ranges between 200 and $250 \mathrm{~m}$ (CHE 2003). The Triassic materials are composed of Buntsandstein facies, abutting at the eastern Paleozoic range, with low hydraulic conductivity and covered by Quaternary materials. The Carbonated Muschelkalk facies is next to (1) the Buntsandstein materials, with moderate hydraulic conductivity due to fracturation, which supplies water to towns in the foothills of the sierras at the eastern part of the lagoon, and (2) the Keuper facies, which covers large areas beneath the Quaternary materials and prevents groundwater flowing between the Triassic and the Quaternary aquifers and between the rest of aquifers in some sections (CHE 2003).

All the aquifers are recharged by rainfall. The Cretaceous and Jurassic aquifer inputs are rainfall at the outcrops that infiltrates through the unsaturated zone, whereas the Quaternary aquifer inputs are rainfall, flows from the Cretaceous and Jurassic aquifers near to the lagoon, and irrigation return flows. Vertical infiltration of ephemeral water flows recharges the Cretaceous and the Triassic aquifers. Lateral infiltration from adjacent aquifers recharges the Cretaceous and the Quaternary Aquifer. Irrigation return flows mainly recharge the Cretaceous and the Quaternary aquifer. On the other hand, Gallocanta Lagoon is the natural discharge area of the GGB. The Quaternary aquifer feeds the lagoon, but losses are also caused by evapotranspiration and groundwater pumping. The Triassic aquifer discharges to springs and to the Quaternary aquifer through lateral flows, whereas discharges from the Cretaceous aquifer also comes from lateral flows to the Quaternary aquifer and from groundwater pumping. Finally, the Jurassic aquifer laterally discharges to the Cretaceous and the Quaternary aquifers, and groundwater directly flows to the lagoon near the north-west shoreline. Therefore, from a hydrogeological perspective, the Cretaceous and Jurassic aquifers are the most relevant, not only because of their hydraulic characteristics but also because of their direct connection to the Quaternary aquifer near the lagoon. On the other hand, the Paleozoic aquifer feeds some springs in the lowest part of the slopes at the eastern boundary of the basin and has very low hydraulic conductivity and little connection, whereas the Triassic one has small size and only the Muschelkalk rocks can store usable amounts of groundwater.

The limits of the GGB are fixed at the eastern and southern areas and mostly coincide with the surface watershed, whereas the western and northern boundaries are hard to delimit due to the absence of faults or diapirs that serve as tectonic boundary (CHE 2003).

Groundwater flow is relatively radial towards the lagoon, but given the shape of the basin, the main flow direction is from west to east. The Cretaceous and Jurassic aquifers, which are independent of each other but both extend across the north-western, western and south-western areas of the lagoon, 


\section{AU'mī}

Hydrogeol J
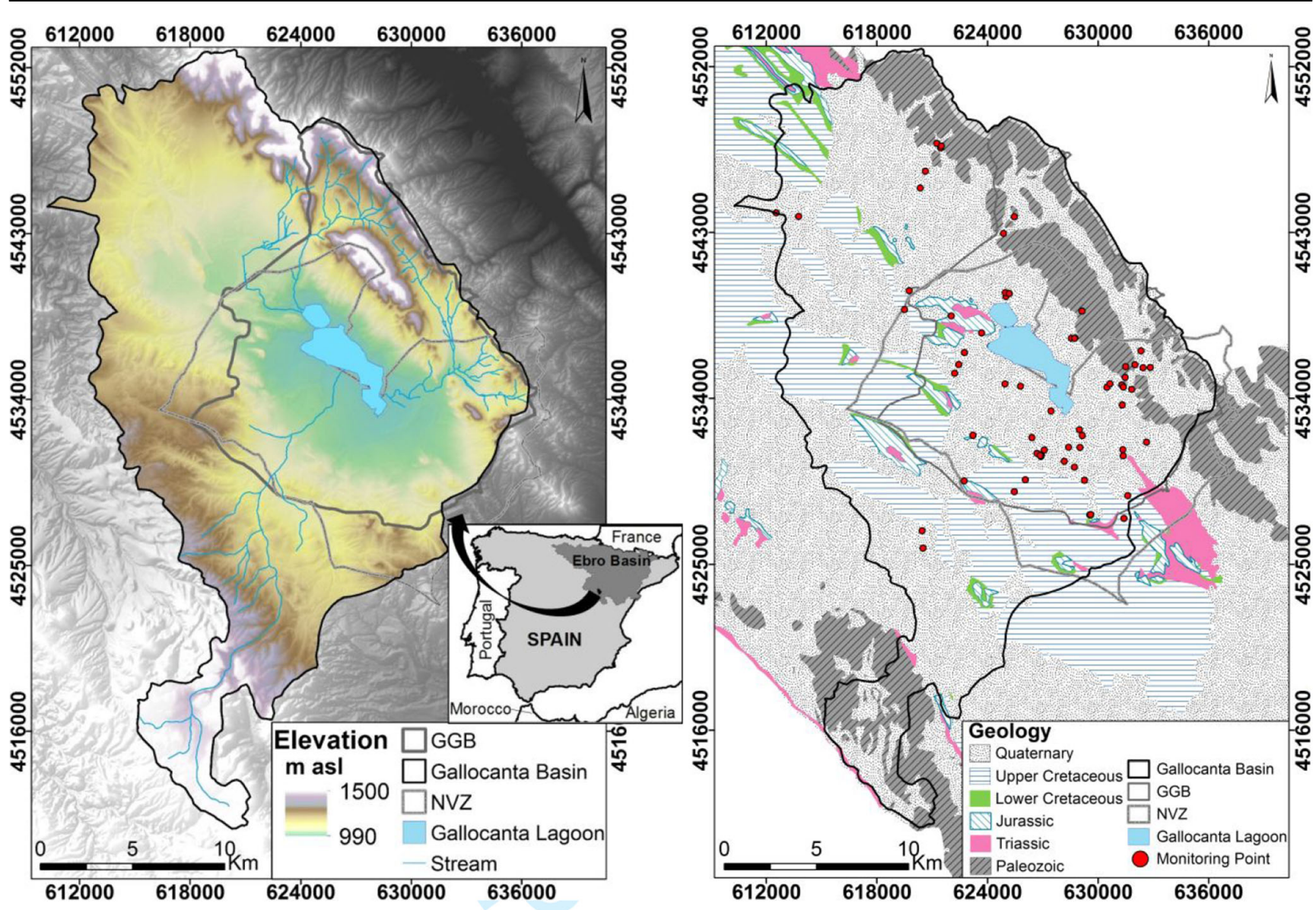

SW

NE

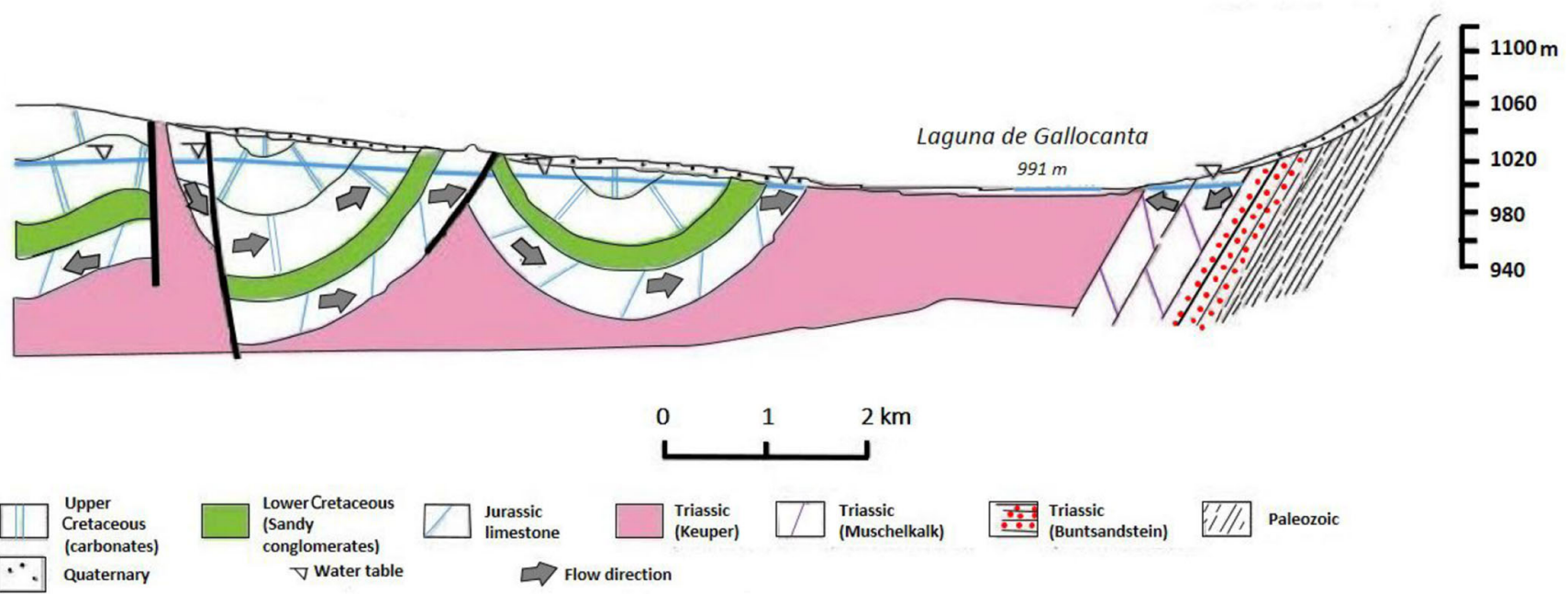

Fig. 1 a Topography and b geology of the Gallocanta Basin, the Nitrate Vulnerable Zone (NVZ) and the groundwater body (GGB) depicted. c are connected to the upper Quaternary aquifer, and significant
Geological cross-section taken from CHE 2003. See the electronic supplementary material (ESM) for further details

aquifers present high temporal variability, being the most influenced by dry periods, whereas the Quaternary aquifer remained less affected by the lack of rainfall, probably due to incorporation of irrigation return flows during the irrigation season (Fig. 2). 

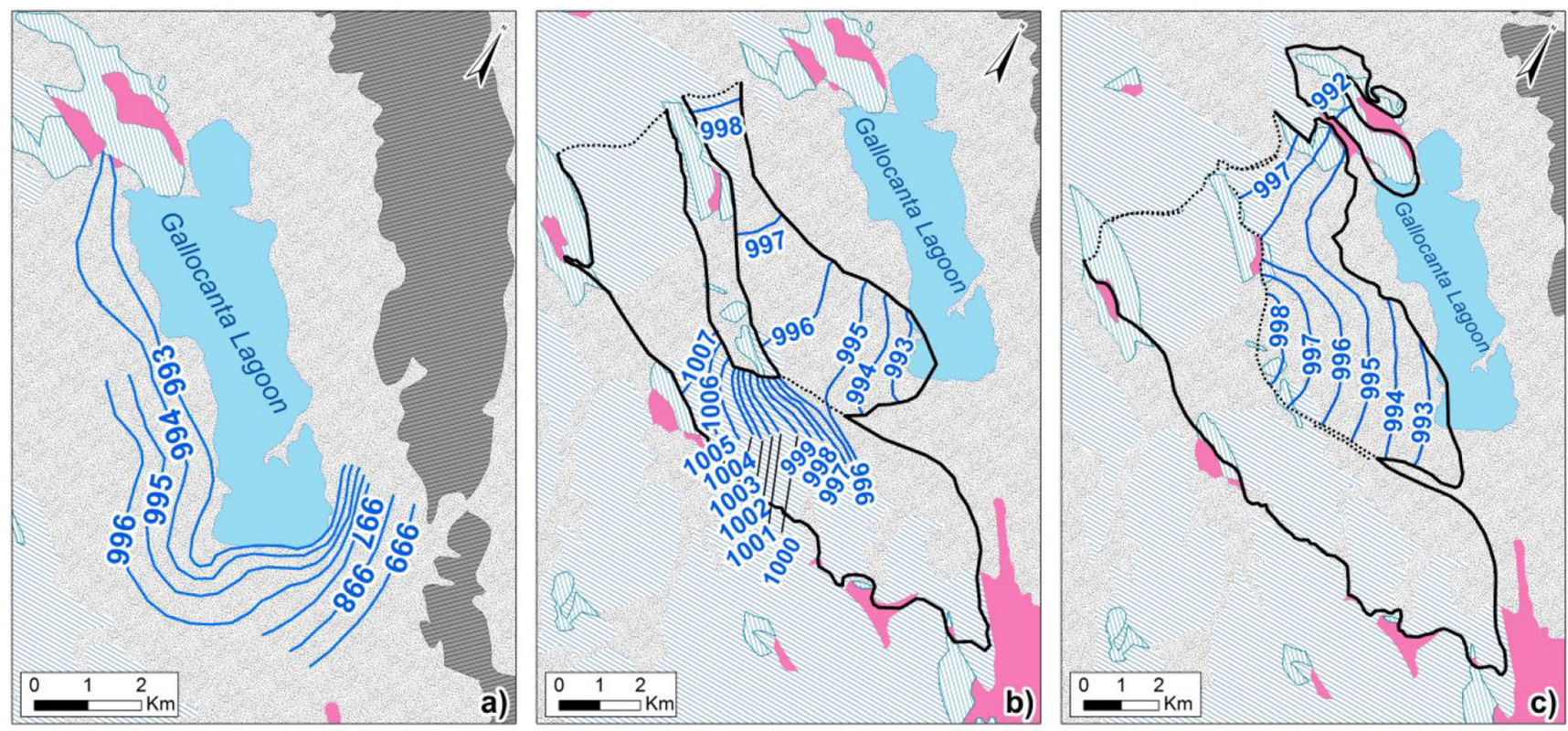

Water-table elevation ( $m$ asl)

Boundary between materials

Water divide

Fig. 2 Isopiezometric lines in the a Quaternary aquifer, $\mathbf{b}$ the Cretaceous aquifer and $\mathbf{c}$ the Jurassic aquifer. Modified from CHE 2003

In the Gallocanta catchment, urban and industrial spots are irrelevant (1\%) since the area is largely occupied by forests $(13 \%)$, semi natural areas (16\%) and arable land (67\%). Most of the agricultural land is rainfed, and winter wheat is the predominant cultivated crop, with fertilization rates ranging from $100-200 \mathrm{~kg} \mathrm{~N} \mathrm{ha}^{-1}$ year $^{-1}$, according to agronomic recommendations followed in the area (López Bellido et al. 2010).

In the last decades, small irrigated areas (about 5 ha) have been developed around the southern and south-western boundary of the lagoon, mainly devoted to potatoes and herbaceous crops. The annual groundwater uptake for irrigation and human usage was estimated to be $1 \mathrm{hm}^{3}$ by the Ebro Hydrographic Confederation (CHE 2003).

The agricultural land extension in the Gallocanta Basin has remained almost unaltered for the last few decades. According to CORINE Land Cover, in 1990 the arable land area was $365 \mathrm{~km}^{2}$, mainly rainfed crops, and in 2018 the extent was $360 \mathrm{~km}^{2}$ (Table 1). Nevertheless, yield was highly variable as it was strongly influenced by several environmental factors, among which rainfall is expected to be one of the main ones (Peña-Gallardo et al. 2019). Median yield obtained between 1986 and 2018 in a control plot was $3,770 \mathrm{~kg} \mathrm{ha}^{-1}$. The maximum yield in that period was obtained in 1989 $\left(7,710 \mathrm{~kg} \mathrm{ha}^{-1}\right)$, whereas in 2001, 2008, 2010 and 2011 the crop was not harvested due to low expected production after visual inspection by farmers (personal interview with farmers).

\section{Available data}

Water quality data were obtained from the CHE database, freely available on the CHE website (CHE 2019). First, all the water quality data available at 70 monitoring stations (674 analysis) distributed across the study area from 1980 to 2018 were collected. The monitoring stations network is composed of boreholes and wells, whose depths range between 3 and $281 \mathrm{~m}$. The network is complemented with some springs. Due to legal requirements from the Water Framework Directive, the monitoring network has experienced significant
Table 1 Agricultural land extent (CORINE Land Cover), yield and average nitrate concentration

$\left(\mathrm{NO}_{3}{ }^{-}\right)$in GGB in 1990, 2000,

2006, 2012 and 2018$$
\text { . }
$$

\begin{tabular}{llll}
\hline Year & Agricultural land area $\left(\mathrm{km}^{2}\right)$ & Wheat yield $\left(\mathrm{kg} \mathrm{ha}^{-1}\right)^{\mathrm{a}}$ & $\mathrm{NO}_{3}^{-}$concentration $\left.(\mathrm{mg} \mathrm{L})^{-1}\right)$ \\
\hline 1990 & 365 & 3,987 & 56.4 \\
2000 & 366 & 7,426 & 57.8 \\
2006 & 363 & 2,776 & 76.9 \\
2012 & 354 & 3,274 & 69.6 \\
2018 & 360 & 4,600 & 66.7 \\
\hline
\end{tabular}

${ }^{\mathrm{a}}$ In a representative control plot 
changes throughout this period. Indeed, the collected data cover stations no longer in use and those included in the current Nitrate Control Network. Available water-table information from 28 monitoring stations from the Official Piezometric Network from the watershed authority (CHE) was also considered for the analysis.

Additionally, data describing the agricultural system in the study area were collected, including both official sources (agricultural statistics collected by the regional administration) and data collated by the farmers' collective. In particular, winter-wheat yield data from 1985 to 2018 in a control plot within the catchment, managed by a municipal farming cooperative located in one of the municipalities in the study area, were analysed to understand the probable nitrogen stock in the soil, and to explore relationships among production and $\mathrm{NO}_{3}{ }^{-}$ concentration in the GGB. Rainfed wheat and barley occupy most of the agricultural land (SIOSE 2018). A significant influence of water availability and drought over winter wheat yield at medium and long time-scale (6-9 months), especially in dry areas, has been reported (Peña-Gallardo et al. 2019). In the Gallocanta Basin, yield is expected to depend mainly on rainfall amount and available water within the soil, so precipitation data have been used to correlate annual yield and $\mathrm{NO}_{3}{ }^{-}$ concentration in the groundwater body.

\section{Data treatment}

The consistency of available data was rather heterogeneous since dates and monitoring frequencies were different during the study period and between sites. To compute an overall mean $\mathrm{NO}_{3}{ }^{-}$concentration, all available records were aggregated to an annual time step, while years with no data or only one measurement were deemed unrepresentative and thus not considered for subsequent analysis. Different aggregation methods (average, median, interpolation of punctual values and surface-weighted average) were tested, but they did not show significant differences among them. For simplicity's sa$\mathrm{ke}$, the average of all available data in a particular year, as indicative of the overall $\mathrm{NO}_{3}{ }^{-}$concentration, was used.

The available data were also analysed on a station by station basis. After an exploratory analysis of the available data, following the recommendations of the Water Framework Directive's Common Implementation Strategy Guideline No. 18 (2009), the monitoring points with sufficient information to perform statistical trends analysis were selected. Out of the 70 monitoring stations, 26 of them fulfilled the criteria of sufficient data (at least 10 samples). Nine of them had records before the NVZ implementation, with an average of 19 samples/station (ranging from 10 to 35 samples). Those nine monitoring points were used to explore trends across the study area before the NVZ implementation, and the remaining 17 stations (19 samples/station, ranging from 10 to 49 samples) complete the analysis after the NVZ came into effect.
Unfortunately, there was no station covering the whole study period, as monitoring networks were significantly modified during the implementation of the Water Framework Directive. Out of the 26 selected monitoring stations, 13 tapped the shallowest Quaternary aquifer, nine of them the Cretaceous aquifer, two of them the Jurassic aquifer, and only one for both the Triassic aquifer and the Palaeozoic aquifer.

\section{Nitrate concentration distribution}

A 6-month classification was used to map the study area. In order to assess and compare the evolution and distribution of $\mathrm{NO}_{3}{ }^{-}$concentration across the study area, maps using $\mathrm{NO}_{3}{ }^{-}$ concentration in spring and autumn were created for three selected years (based on the amount of available data and the coincidence with beginning of records, NVZ implementation and the more recent available data): 1981, 1999 and 2017. In addition, data were separately treated and presented for each single aquifer.

\section{Nitrate time series}

The overall $\mathrm{NO}_{3}{ }^{-}$trend analysis was calculated for data from 1980 to 2018. Considering 2000 to be the year that the I Action Programme was implemented, a distinction in trend performance was made. Separated trend analyses were carried out for data from 1980 to 2000, and from 2001 to 2018, for the whole study area and for each single aquifer. The nonparametric Mann-Kendall test, using a 95\% significance level, was applied to detect significant trends both during the whole study period and during each stage (pre and post NVZ implementation). The non-parametric Mann-Kendall test is one of the most used for trend analysis in hydrological data and it has been shown to be effective in detecting trends (e.g. Hirsch et al. 1982, 1991; Yue et al. 2002; Yue and Pilon 2004; Gonzales-Inca et al. 2016; Urresti-Estala et al. 2016; Musacchio et al. 2019). The magnitude of the increasing and decreasing trends (in $\mathrm{mg} \mathrm{L}^{-1}$ year $^{-1}$ ) was calculated by using Sen's slope. In addition, the non-parametric Wilcoxon ranksum test was used to explore the differences in $\mathrm{NO}_{3}{ }^{-}$concentration before and after the NVZ implementation.

The Mann-Kendall test and Sen's slope were also individually applied to the 26 selected monitoring stations and their trends were classified as nonsignificant, decreasing, or increasing. The 26 monitoring stations were also classified based on the aquifer they tap and Wilcoxon rank-sum test was applied to find differences in $\mathrm{NO}_{3}{ }^{-}$concentration among aquifers. Besides, in order to explore the relationship between water level and $\mathrm{NO}_{3}{ }^{-}$concentration in the aquifer, three stations tapping different aquifers and with both water-level and $\mathrm{NO}_{3}{ }^{-}$data available were selected for the assessment. Trend analysis and statistical comparisons were performed using the 
Hydrogeol J

408 MAKESENS template (Salmi et al. 2002) and the R software

409 (R Development Core Team 2016).

\section{$410 \quad$ Results}

\section{Nitrate concentration dynamics}

The $\mathrm{NO}_{3}{ }^{-}$concentration at most of the monitoring stations in the GGB is high. The median $\mathrm{NO}_{3}{ }^{-}$concentration in the study area from 1980 to 2017 was $57.2 \mathrm{mg} \mathrm{L}^{-1}$ (maximum = $311 \mathrm{mg} \mathrm{L}^{-1}$ and minimum $=0.1 \mathrm{mg} \mathrm{L}^{-1}$ ) and the average concentration was $66.0 \mathrm{mg} \mathrm{L}^{-1}$. Regarding the Nitrates Directive thresholds, $58.9 \%$ of the samples were above $50 \mathrm{mg} \mathrm{L}^{-1}$ and only $16.5 \%$ were below $25 \mathrm{mg} \mathrm{L}^{-1}$ (unaffected waters).

\section{Spatial patterns}

In relation to the stations that were polluted throughout the study period, most of them were located in the southern and western parts of the groundwater body (Fig. 3). These stations tapped the Cretaceous, the Jurassic and the Quaternary aquifers and all of them far exceeded concentrations above $50 \mathrm{mg} \mathrm{L}^{-1}$. Stations located in the eastern and northern parts of the GGB, which tapped the Jurassic, Quaternary, Triassic and Paleozoic aquifers, showed lower concentrations. Concentrations in some of the stations located far from the groundwater boundary or at the foot of the Sierra de Santa Cruz remained low during the 30 years of study, even under the limit of $25 \mathrm{mg} \mathrm{L}^{-1}$.

During the study period, the Cretaceous aquifer was the most affected (mean $\mathrm{NO}_{3}{ }^{-}=77.4 \mathrm{mg} \mathrm{L}^{-1}$ ), followed by the Quaternary (mean $=74.7 \mathrm{mg} \mathrm{L}^{-1}$ ), the Jurassic (mean = $60.2 \mathrm{mg} \mathrm{L}^{-1}$ ) and the Triassic (mean $=45.2 \mathrm{mg} \mathrm{L}^{-1}$ ). There were significant differences in $\mathrm{NO}_{3}{ }^{-}$concentration between the Quaternary and the Triassic aquifers $(p<0.001)$, the Quaternary and the Jurassic $(p=0.019)$, the Jurassic and the Cretaceous $(p<0.001)$, and between the Cretaceous and the Triassic aquifers $(p<0.001)$, but not between the Quaternary and the Cretaceous ones, which are the most polluted.

\section{Temporal variation}

In general, $\mathrm{NO}_{3}{ }^{-}$concentration was higher in spring at most of the points and in most years, although some years presented an inverse pattern, with higher $\mathrm{NO}_{3}{ }^{-}$concentration in autumn (Fig. 3). These differences are associated with the distribution of rainfall across seasons in any particular year. During the study period, the Cretaceous aquifer constantly recorded mean $\mathrm{NO}_{3}^{-}$concentrations above $50 \mathrm{mg} \mathrm{L}^{-1}$ since 1980 , while the Quaternary remained below the Nitrates Directive threshold
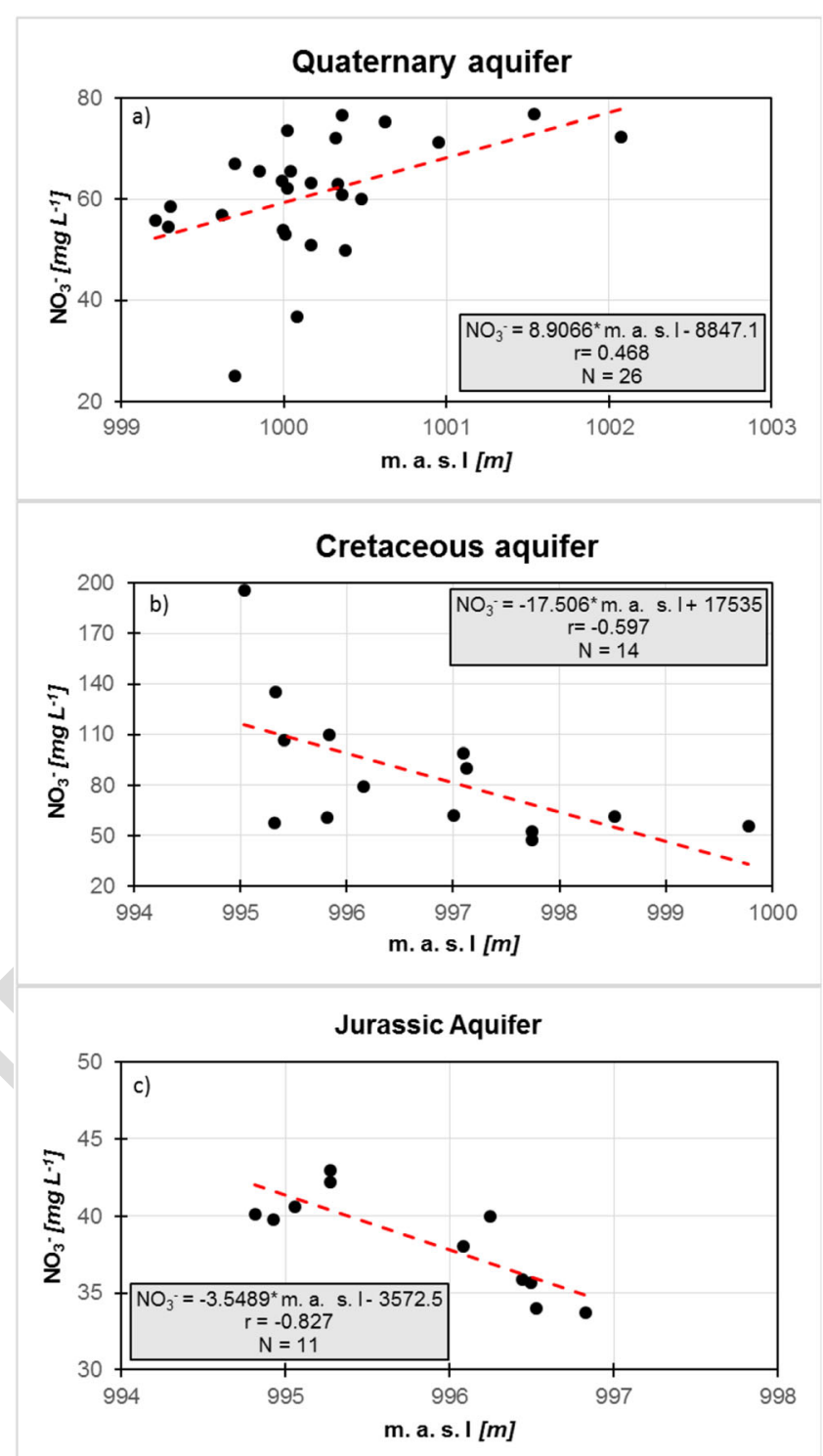

Fig. 3 Mean nitrate concentration $\left(\mathrm{mg} \mathrm{L}^{-1}\right)$ in the Paleozoic, Triassic, Jurassic, Cretaceous and Quaternary aquifers in a spring 1981, b spring 1999, c spring 2017, d autumn 1981, e autumn 1999 and f autumn 2017. Symbols represent the sampling points associated with nitrate concentrations

until the mid-1980s. However, mean concentration within the Jurassic aquifer fluctuated since 2001.

The results showed a different behaviour in $\mathrm{NO}_{3}{ }^{-}$dynamics depending on the aquifer, likely pertaining to the Cretaceous and the Jurassic aquifers, since both showed lower concentrations when the water table was higher (Fig. 4). Both aquifers have been observed to be widely polluted and extend across the western, south-western and southern areas of the groundwater body and they are respectively characterized by medium and high hydraulic conductivity due to fissuring and karstification. 


\section{AU'mī}

Hydrogeol J

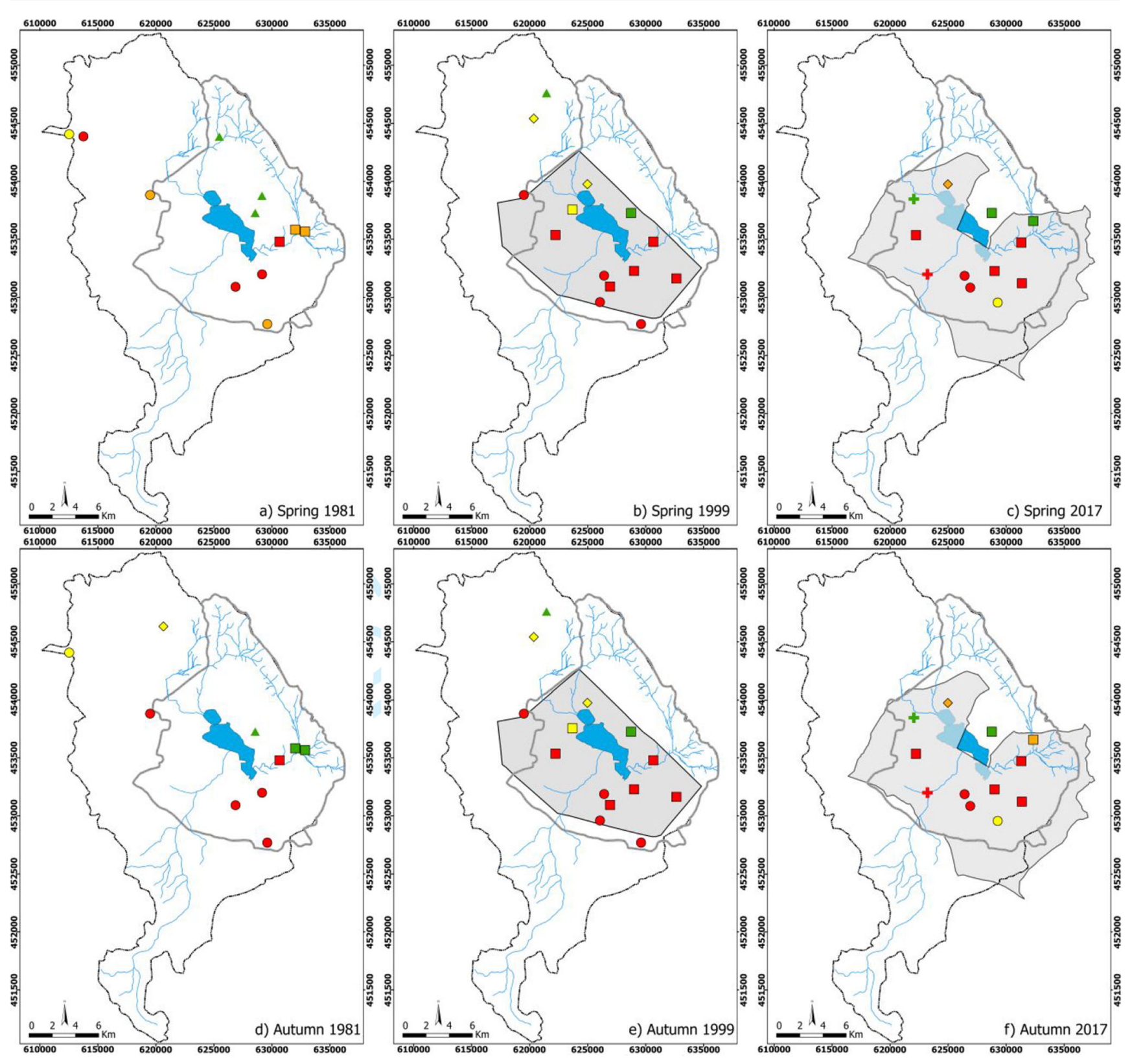

Paleozoic

$\begin{array}{llllll}\Delta & <25 & 25-40 \quad 40-50 \quad \Delta \quad & > & 40\end{array}$

Triassic

$\diamond<25 \diamond \quad 25-40 \diamond \quad 40-50 \diamond \quad>50$

Jurassic

$+<25 \neq 25-40+40-50+>50$

Cretaceous

$\begin{array}{llllllll}0 & <25 & \bigcirc & 25-40 & \bigcirc & 40-50 & \bigcirc & >50\end{array}$

Quaternary

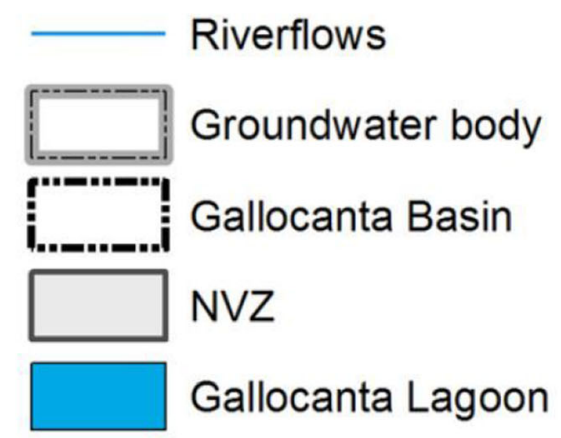

$\square \quad<25 \quad \square \quad 25-40 \quad \square \quad 40-50 \quad \square \quad>50$ 
Hydrogeol J

Fig. 4 Relationship between nitrate concentration $\left(\mathrm{NO}_{3}{ }^{-}\right)$and water table in representative monitoring stations in the a Quaternary, b Cretaceous, and $\mathbf{c}$ Jurassic aquifers

\section{Long-term trends}

The results showed how average $\mathrm{NO}_{3}{ }^{-}$concentration continuously increased from the late 1970s until mid-2000 (Fig. 5). From 2007, $\mathrm{NO}_{3}{ }^{-}$concentration decreased until 2013 and then increased again until 2018. Overall, trend analyses highlight a significant increasing trend in $\mathrm{NO}_{3}{ }^{-}$concentration from 1980 to 2018 in the area $(p=0.003)$, peaking in 2007 (average $=106 \mathrm{mg} \mathrm{L}^{-1} ; n=15$ ). The annual magnitude of increase was $0.54 \mathrm{mg} \mathrm{L}^{-1}$ year $^{-1}(p<0.01)$. Considering all available samples, the average $\mathrm{NO}_{3}^{-}$concentrations were $57.7 \mathrm{mg} \mathrm{L}^{-1}$ and $72.1 \mathrm{mg} \mathrm{L}^{-1}$ during the pre- and post-NVZ implementation stages, respectively.

Focusing on the trend analysis of the 26 selected monitoring points, out of the nine suitable for trend analysis before 2000 , none of them recorded decreasing trends, $78 \%$ had nonsignificant trends, and $22 \%$ had increasing trend (Table 2). The magnitude of those trends was between 1.3 and $2.4 \mathrm{mg} \mathrm{L}^{-1}$ year $^{-1}$ and $66 \%$ of the sites were above the Nitrates Directive threshold of $50 \mathrm{mg} \mathrm{L}^{-1}$. The stations with increasing trends tapped the Cretaceous and the Quaternary aquifers. After the NVZ implementation, remarkable differences were found, i.e. out of the 17 stations, $24 \%$ showed decreasing trends, $42 \%$ had nonsignificant trends, and $18 \%$ were increasing. In addition, the ranges of decreasing and increasing magnitude were -2.7 to -0.7 and 0.2 to $0.6 \mathrm{mg} \mathrm{L}^{-1}$ year $^{-1}$, respectively (Table 2 ), with differences in the increasing-trend magnitudes $(p=0.05)$. The monitoring stations with increasing trend tapped the Jurassic, the Quaternary and the Triassic aquifers, whereas the stations with decreasing trends tapped the Cretaceous and also the Jurassic and the Quaternary aquifers. A higher proportion of decreasing trends was found in stations with concentrations above
$50 \mathrm{mg} \mathrm{L}^{-1}$ whereas increasing trends were detected in already affected stations and in stations at risk. As mentioned previously, stations with low concentrations remained unaffected during the study period.

The highest increasing trends were located around the south and south-western parts of the lagoon, whereas the decreasing trends were at the central part of the NVZ (Fig. 6). Until the NVZ implementation, strong and significant increasing trends took place in the zone (Fig. 6), and after the implementation, the patterns appear to have changed and nondetected or decreasing trends are evident (Fig. 6).

\section{Discussion}

\section{Nitrate patterns in Gallocanta}

Groundwater nitrate concentrations in the GGB have been increasing since the late 1970s. High concentrations were already registered in the early $1980 \mathrm{~s}$ (mean of $44.8 \mathrm{mg} \mathrm{L}^{-1}$ in 1980) and the results suggested that use of nitrogen fertilizer has increased since then, probably due to lower prices and ease of application (Ahmed et al. 2017). The average $\mathrm{NO}_{3}{ }^{-}$ concentration continued to increase seven years after the NVZ implementation, then it started to decrease until 2013. Since then, the trend has fluctuated (Fig. 5). It is hard to distinguish whether that rise is due to (1) the necessary time lag to observe improvements attributed to the NVZ Action Programmes implemented for the first time in 2000, or (2) the lack of application of the measures of the action programmes. Indeed, a large range of variation has been reported in the time lag required for a response in $\mathrm{NO}_{3}{ }^{-}$dynamics after a change in $\mathrm{N}$ fertilizer application (Vero et al. 2018). For instance, time lags of decades have been observed in groundwater and surface water in northern mainland Europe (Kronvang et al. 2008; Sohier et al. 2009), whereas time lags of less than a year were reported in surface-water bodies in the UK (Worrall et al.
Fig. 5 Annual average (red dots) and trend (dashed line) in nitrate concentration $\left(\mathrm{NO}_{3}{ }^{-}\right)$in

Gallocanta Groundwater Body during the period 1980-2018. All $\mathrm{NO}_{3}{ }^{-}$data used to compute the average and trends are presented (black dots)

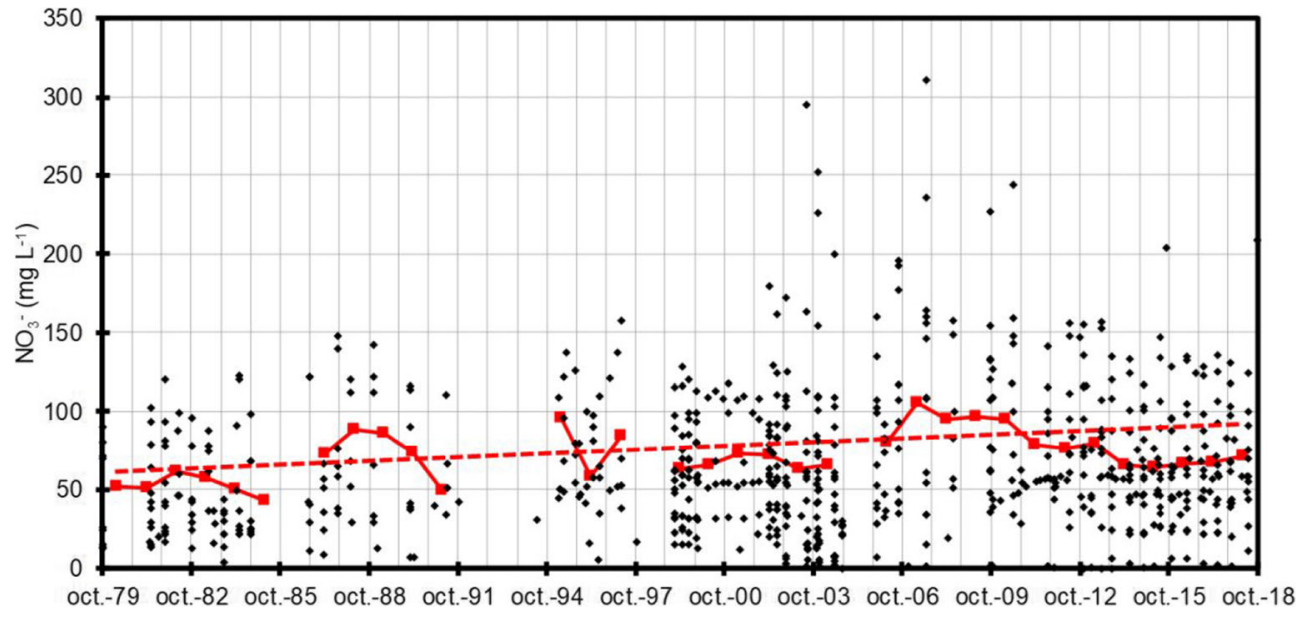


t2.1 Table 2 Nitrate concentration trends in the 26 selected monitoring points during the periods of pre- and post-Nitrate Vulnerable Zone (NVZ) implementation

\begin{tabular}{|c|c|c|c|c|c|c|c|}
\hline Designation & $n$ & $\begin{array}{l}\text { Increasing } \\
\text { trend }(\%)\end{array}$ & $\begin{array}{l}\text { Nondetected } \\
\text { trend }(\%)\end{array}$ & $\begin{array}{l}\text { Decreasing } \\
\text { trend }(\%)\end{array}$ & $\begin{array}{l}\text { Range of increasing trend } \\
\left(\mathrm{mg} \mathrm{L}^{-1} \text { year }^{-1}\right)\end{array}$ & $\begin{array}{l}\text { Range of decreasing trend } \\
\left(\mathrm{mg} \mathrm{L}^{-1} \text { year }^{-1}\right)\end{array}$ & $\begin{array}{l}\% \text { Above } \\
50 \mathrm{mg} \mathrm{L}^{-1}\end{array}$ \\
\hline Pre-NVZ & 9 & 22 & 78 & - & $+1.3-+2.4$ & - & 67 \\
\hline
\end{tabular}

2009) or groundwater bodies in Spain (Kuhn et al. 2011). In the Gallocanta basin, CHE (2003) showed that time lag in the area surrounding the lagoon was up to 10 years. In any case, the necessary delay between measures implementation and water quality response and its dependence on farmer behaviour and catchment characteristics has been highlighted in several studies (e.g. Kronvang et al. 2008; Burt et al. 2011; Wang et al. 2016). In the GGB case, the hydrological and social context suggested that the low effectiveness of the measures adopted by farmers explains the rising concentration after the NVZ implementation, since the aquifers have shown rather significant responses to changes in water inputs and/or $\mathrm{NO}_{3}{ }^{-}$on a year to year basis (Kuhn et al. 2011).

Despite this, the NVZ implementation could have had slight but still positive influence over $\mathrm{NO}_{3}{ }^{-}$concentration, according to the performed trend analysis. Indeed, although not apparent in actual concentrations, significant improvements were observed in both the percentage of stations showing increasing or decreasing trends, and the magnitude of the increasing trends when comparing pre-NVZ and post-NVZ
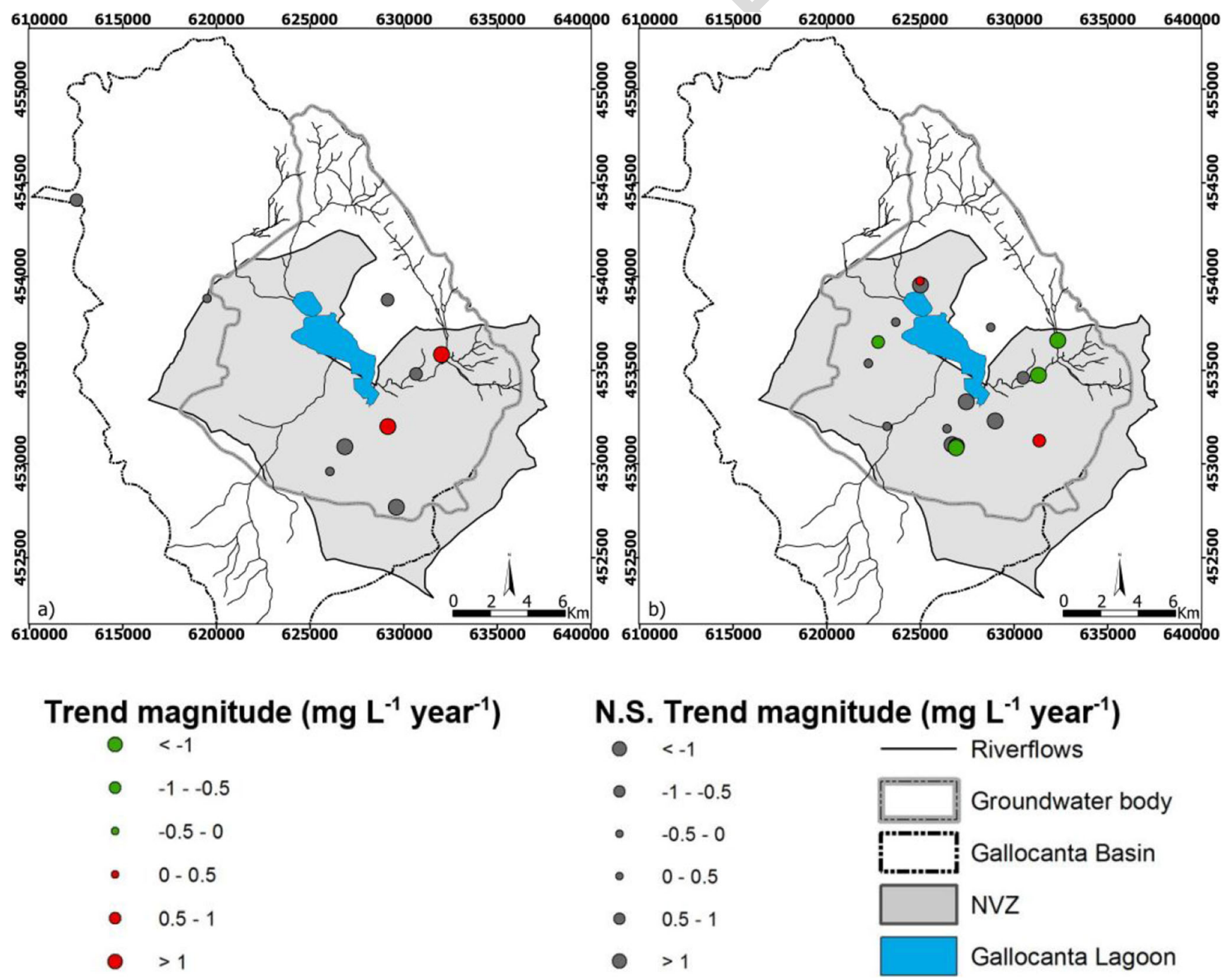

Fig. 6 Trend magnitude (mg L ${ }^{-1}$ year $^{-1}$ ), computed as Sen's slope, during the a pre-NVZ period and the b post-NVZ period 
Hydrogeol J

548 concentrations at the selected stations. These observations 549 could indicate a change in pattern introduced by good agricul550 tural practices in the area. This idea is also supported by the 551 relatively stable agricultural land uses in Gallocanta. In the last 552 decades, the area of agricultural land and type of crops have 553 remained unaltered; therefore, changes in groundwater nitrate 554 concentration could have been caused by changes in nitrogen 555 input.

Regarding the spatial distribution of trends, the Jurassic and the Cretaceous aquifers showed lower nitrate concentrations when the water table was higher, mainly due to the fissuring and karstification. As a consequence, recharge water can easily reach the water table throughout outcrops and its vulnerability to pollution is high. However, simultaneously, unpolluted water from rain can quickly get into the aquifer and the consequent higher water table helps to decrease $\mathrm{NO}_{3}{ }^{-}$concentration through dilution. Similar patterns have been observed worldwide, e.g. in Italy (Rotiroti et al. 2019) or in the US (Böhlke et al. 2007). On the other hand, the detritic Quaternary aquifer is fed by direct vertical recharge from the vadose zone, which leached $\mathrm{NO}_{3}{ }^{-}$on its way down, and by groundwater flow from the Cretaceous and Jurassic aquifers. This $\mathrm{NO}_{3}{ }^{-}$may reach the Quaternary aquifer and then increase in concentration. The mean $\mathrm{NO}_{3}{ }^{-}$concentration was very high in this aquifer during the study period. The $\mathrm{NO}_{3}{ }^{-}$concentration remained low at monitoring points with less than $25 \mathrm{mg} \mathrm{L}^{-1}$, whereas the greatest decreasing trends were found at stations with $\mathrm{NO}_{3}{ }^{-}$concentration above the threshold of $50 \mathrm{mg} \mathrm{L}^{-1}$. Sampling points with the highest mean concentration were located at the southern part of the lagoon, near to lowlands and irrigated areas, which likely contribute irrigation return flows to the aquifer according to observations reported in other study cases (Andrés and Cuchí 2014; Merchán et al. 2015). In fact, high $\mathrm{NO}_{3}{ }^{-}$concentration in drinking water wells in this area have recurrently caused restrictions to public water supply in the past in several towns of the study area, as reported in local newspapers (e.g. Heraldo de Aragón September 20th 2015; Gallocanta Town Council November 18th 2019).

In spite of the apparent improvement, it cannot be omitted that after almost 20 years and four action programmes, the improvements clearly are below expectations and should be considered as insufficient, since current $\mathrm{NO}_{3}{ }^{-}$concentration is even higher than in 2000. In addition, for those stations with declining trends, it would take several decades to achieve recommended levels by the Nitrates Directive, given the estimated trends in this study.

The results are in line with other studies within NVZs. The assessment of $\mathrm{NO}_{3}{ }^{-}$trends in groundwater has been studied both in NVZs (Arauzo and Valladolid 2011, Arauzo and Martínez-Bastida 2015; Mussachio et al. 2016) and in nonNVZs (Batlle Aguilar et al. 2007; Hansen et al. 2011; Lopez et al. 2015) in several regions within the European Union.
These studies underline that groundwater pollution is an issue across Europe and the situation is far from being solved. For instance, Urresti-Estala et al. (2016) found no improvements in water quality in sectors of an extensive catchment in southern Spain with agricultural land as the main land use, whereas Rojek et al. (2017) reported higher increasing trends in NVZs than those in non-NVZs in Poland. Studies carried out in countries that declared its entire surface as an NVZ showed, in general, better results in decreasing $\mathrm{NO}_{3}{ }^{-}$and reversal trends have been reported (Visser et al. 2007; Kronvang et al. 2008; Hansen et al. 2011). For the success of NVZ implementation, these authors emphasize the consideration of local conditions, the need of stricter control measures and the proper NVZ delineation for the success of $\mathrm{NVZ}$ implementation.

\section{Adequacy of NVZ delimitation and effectivity of action programmes}

The definition of NVZ included in the Nitrates Directive refers to all known areas of land in their territories which drain into the waters affected (and which could be affected) and which contribute to pollution (Nitrates Directive, Art. 3). This definition includes a clear hydrological/hydrogeological connotation, which means that feasible $\mathrm{NO}_{3}{ }^{-}$sources in the whole basin draining into a water body should be declared; however, within the endorheic Gallocanta Basin, only $38 \%$ of the surficial watershed is under NVZ designation. The nitrate vulnerable zone surrounds the lagoon and it occupies the lowlands of the basin, while in the highlands, which are predominantly rainfed agricultural lands, no fertilizer restrictions are in order. Given the hydrological and hydrogeological continuity among these domains, it is very likely that surface water or interflow leach available nitrogen in soils of agricultural plots at the higher lands and flow to the lowest areas, transporting $\mathrm{NO}_{3}{ }^{-}$, where it infiltrates into the aquifers. It is well proven within scientific literature that time lags may prevent the NVZ from achieving $\mathrm{NO}_{3}{ }^{-}$reduction goals within the designated periods (Vero et al. 2018). Although, according to $\mathrm{CHE}$ (2003), time lag in the area surrounding the lagoon is up to 10 years, distant zones have longer time lags due to the distance from the lowlands. Those areas supply nitrate to the protected area a long time after the nitrogen was applied. This flux complicates the proper functioning of the NVZ not only in the present, but also in the next decades, so any measure taken within the NVZ would be masked by pollutant fluxes from adjacent areas. The declaration of the whole basin as an NVZ would help to control the nitrogen input and, thus, to improve the groundwater quality in the long term. Indeed, this is not the only case in which an NVZ does not follow hydrological considerations, as similar cases have been reported in other catchments in Spain (e.g. Arauzo and Valladolid 2011). From the revelations already mentioned, it is clear that
616

617 
hydrological knowledge of the water body should be considered in NVZ designation.

Both the Nitrates Directive and the action programmes mention the control measures, but, in general, they are vague and do not include specifications about frequency of control measures, responsibility for action, or applicable sanctions. A way to promote farmers' reduction in fertiliser use could be an increase in the control of the level of compliance within the action programmes measures and economic imperatives. In relation to economic matters, higher cost of fertiliser or stricter economic bans may also reduce and/or optimize the use of fertiliser. In fact, evidence of water quality improvements as a result of the combination of economic imperatives and legislative requirements has been reported in the UK (Macgregor and Warren 2015). Indeed, the capital role of farmers, stakeholders and governance configuration in the success of the action programmes has been highlighted in several studies (Trifu et al. 2013; MacGregor and Warren 2015; Musacchio et al. 2019). These studies emphasize the need to involve and convince farmers and to make them part of the decisionmaking process, since they are a key part in the achievement of a good water quality status. Additionally, it can be concluded that actions on a voluntary basis without economic incentives are destined to failure.

From a legal approach, after four action programmes (2000, 2005, 2009 and 2013) yielding only minor improvements in groundwater quality, these programs still opt for continuing to apply the same measures over and over. Those measures basically are related to fertilize application rates based on the type of crop, the type of fertiliser, the water management regime and the soil characteristics. According to the Nitrates Directive, additional or reinforcing measures have to be implemented if no improvements are detected. The Nitrates Directive also established that a new action programme should have been already implemented. The nonfulfillment of the Nitrates Directive in relation to the renewal of the action programmes is indicative of the lack of control of the NVZ. The current action programme measures attempt to control nitrogen output by limiting inputs either directly by agreement with land owners or indirectly by subsidizing landuse changes away from high-input crops, as has been done, for instance, in the UK (Worrall et al. 2009). In the light of the results, this approach could not be the most effective, especially in rural and extensive rainfed areas such as the Gallocanta Basin.

\section{Particularities of endorheic watersheds}

From an environmental perspective, endorheic basins in dry and semi-arid regions are particularly vulnerable to pollution because of their low precipitation and high evaporation rates (Schütt 1998). Since no other output but evapotranspiration is possible, one of the main components in the mass balance typical of other watersheds (i.e. losses through river or aquifer flow to downstream water bodies) is missing. Consequently, the water renewal rate in endorheic basins is in general lower than in nonendorheic ones and any pollutant incorporated in the system lacking significant gaseous losses is likely to build up in water bodies.

In the study case, GGB is associated to an endorheic basin draining into Gallocanta lagoon. This fact supposes a significant challenge for water management for the aforementioned reasons. Indeed, one of the main components in the nitrogen balance in many watersheds is associated to $\mathrm{NO}_{3}{ }^{-}$losses in river flow, which are mainly missing in this case. Although there is some evidence of a likely hydrological connection of GGB with other nonendorheic water bodies (Jiloca River), further research is on course regarding this issue. The current knowledge of the system suggests that water (and nitrogen) losses to other water bodies are a minor component of the balance in this particular case.

Regarding $\mathrm{N}$ gaseous losses, previous studies in other Spanish endorheic saline lakes have showed significant attenuation of $\mathrm{NO}_{3}{ }^{-}$in the lake-aquifer system by heterotrophic denitrification (Gómez-Alday et al. 2014) and denitrification processes related to organic carbon oxidation in the surrounding area of the lake and the freshwater-saltwater interface (Valiente et al. 2018). Although there are no available data on gaseous $\mathrm{N}$ losses in GGB, the low $\mathrm{NO}_{3}{ }^{-}$concentration observed in the lagoon (mean concentration $=6.1 \mathrm{mg} \mathrm{L}^{-1}$ ) suggests that natural attenuation processes play a key role for decreasing $\mathrm{NO}_{3}{ }^{-}$in the basin. Among them, denitrification could be highlighted. Given the relatively high greenhouse effect associated to denitrification ( $\mathrm{NO}$ and/or $\mathrm{N}_{2} \mathrm{O}$ losses), the fact that this loss replaces losses to downstream water bodies deserves further attention in future research.

\section{Conclusion}

Assessing the effectiveness of NVZs by using long-time series data is a necessary step for testing the level of success of the Nitrates Directive policies. Twenty years after the NVZ implementation at Gallocanta, mean $\mathrm{NO}_{3}{ }^{-}$concentration was still above the threshold of $50 \mathrm{mg} \mathrm{L}^{-1}$, which led to the conclusion that the lack of application of the action programmes and the inadequate delimitation of the NVZ seem to be the main causes of the failure of the implementation. Both factors allow uncontrolled nitrate input in the groundwater system and thus mask any likely improvement achieved by the correct implementation of the measures at the NVZ. Hydrogeological functioning of the system may also be influenced by natural factors such as the necessary time lag from the implementation of the measures to the observation of improvement, although it has been shown that this cannot explain the minor decreasing trends observed in the whole basin. After 20 years, slight 
advances have been achieved and the rate of change would take decades to reach compliance with legal requirements, which was already unmet in 2015. After the NVZ implementation, decreasing trends were observed in some long-term monitoring stations, but the general trend of the area has been fluctuant across the study period, so the necessary improvement driven by the mitigation measures cannot be confirmed. Given that stoppages in water supply due to high $\mathrm{NO}_{3}{ }^{-}$concentration in groundwater have affected several towns in the area, the lack of an alternative for supplying drinking water to the population, and the current concern about $\mathrm{NO}_{3}{ }^{-}$pollution in the European Union, stricter measures and changes in the Nitrates Directive application should be considered in the short term.

Acknowledgements The authors also wish to acknowledge the support of Felipe Delgado (Confederación Hidrográfica del Ebro) for providing official information (internal reports).

Funding information This work was undertaken thanks to a pre-doctoral grant awarded by the Government of Aragon to J. M. Orellana (BOA 20/ 07/2017). The work received funding from "Ministerio de Economía y Competitividad" via the Research Project AGRO-SOS (CGL201566016-R), and it was also supported by the "Juan de la Cierva Formación” program, FJCI-2016-24,920; Research Project CGL201564284-C2-1-R awarded to D. Merchán.

\section{References}

Ahmed M, Rauf M, Mukhtar Z, Saeed NA (2017) Excessive use of nitrogenous fertilizers: an unawareness causing serious threats to environment and human health. Environ Sci Pollut Res 24:2698326987. https://doi.org/10.1007/s11356-017-0589-7

Andrés R, Cuchí JA (2014) Analysis of sprinkler irrigation management in the LASESA district, Monegros (Spain). Agric Water Manag 131: 95-107. https://doi.org/10.1016/j.agwat.2013.09.016

Arauzo M (2017) Vulnerability of groundwater resources to nitrate pollution: a simple and effective procedure for delimiting nitrate vulnerable zones. Sci Total Environ 575:799-812. https://doi.org/10. 1016/j.scitotenv.2016.09.139

Arauzo M, Valladolid M, Martínez-Bastida JJ (2011) Spatio-temporal dynamics of nitrogen in river-alluvial aquifer systems affected by diffuse pollution from agricultural sources: implications for the implementation of the nitrates directive. J Hydrol 411:155-168. https:// doi.org/10.1016/j.jhydrol.2011.10.004

Arauzo M, Martínez-Bastida JJ (2015) Environmental factors affecting diffuse nitrate pollution in the major aquifers of Central Spain: groundwater vulnerability vs. groundwater pollution. Environ Earth Sci 73:8271-8286. https://doi.org/10.1007/s12665-0143989-8

Batlle Aguilar J, Orban P, Dassargues A, Brouyère S (2007) Identification of groundwater quality trends in a chalk aquifer threatened by intensive agriculture in Belgium. Hydrogeol J 15:1615-1627. https://doi. org/10.1007/s10040-007-0204-y

BOE (1996) RD 261-1996 Sobre protección de las aguas contra contaminación por nitratos de fuentes agrarias [RD 261-1996
Water Protection against nitrate pollution from agricultural sources]. BOE 61, Government of Spain, Madrid, pp 9734-9737

Böhlke JK, Verstraeten IM, Kraemer TF (2007) Effects of surface-water irrigation on the sources, fluxes, and residence times of water, nitrate, and uranium in an alluvial aquifer. Appl Geochem 2:152-174. https://doi.org/10.1016/j.apgeochem.2006.08.019

Burt TP, Howden NJK, Worrall F, Whelan MJ, Bieroza M (2011) Nitrate in United Kingdom rivers: policy and its outcomes. Environ Sci Technol 45:175-181

CHE (Confederación Hidrográfica del Ebro) (2003) Establecimiento de las normas de explotación de la unidad hidrogeológica "Gallocanta" y delimitación de los perímetros de protección de la laguna [Establishing the rules of use of the hydrogeologic unit of Gallocanta and delimitation of the protected area of the lagoon]. Confederación Hidrográfica del Ebro, Zaragoza, Spain

CHE (Confederación Hidrográfica del Ebro) (2012) Informe sobre la determinación de las aguas afectadas o en riesgo de contaminación por nitratos de origen agrario en la demarcación del Ebro. Periodo (2008-2011) [Report of the polluted and at risk water bodies by nitrates from agricultural sources within the Ebro Basin (20082011)]. Confederación Hidrográfica del Ebro, Zaragoza, Spain

CHE (Confederación Hidrográfica del Ebro) (2016) Informe sobre la determinación de las aguas afectadas o en riesgo de contaminación por nitratos de origen agrario en la demarcación del Ebro. Periodo (2012-2015) [Report of the polluted and at risk water bodies by nitrates from agricultural sources within the Ebro Basin (20122015)]. Confederación Hidrográfica del Ebro, Zaragoza, Spain

CHE (Confederación Hidrográfica del Ebro) (2018) Homepage. http:/ www.chebro.es/. Accessed 10 April 2019

Development Core Team R (2016) R: a language and environment for statistical computing. R Foundation for Statistical Computing, Vienna

European Commission (2009) Common implementation strategy for the Water Framework Directive: guidance on groundwater status and trend assessment, no. 18. European Commission, Brussels

European Commission (2010) Report from the Commission to the Council and the European Parliament. European Commission, Brussels

European Commission (2018) Report on the implementation of Council Directive 91/676/EEC concerning the protection of waters against pollution caused by nitrates from agricultural sources based on Member State reports for the period 2012-2015. European Commission, Brussels

European Economic Community (1991) Council Directive 91/676/EEC. 1-8. European Economic Community, Brussels

Fraters B, Kovar K, Willems WJ, Stockmarr J, Grant R (2005) Monitoring effectiveness of the EU Nitrates Directive Action Programmes. Results of the international MonNO3 workshop, 1112 June 2003. Dutch National Institute for Public Health and the Environment, Bilthoven, The Netherlands

Fraters B, Kovar K, Grant R, Thorling L, Reijs JW (2011) Developments in monitoring the effectiveness of the EU Nitrates Directive Action Programmes. Results of the second MonNO3 workshop, 10-11 June 2009. Dutch National Institute for Public Health and the Environment, Bilthoven, The Netherlands

Gobierno de Aragón (1997) DECRETO 77/1997, de 27 de mayo, del Gobierno de Aragón, por el que se aprueba el Código de Buenas Prácticas Agrarias de la Comunidad Autónoma de Aragón y se designan determinadas áreas Zonas Vulnerables a la contaminación de las aguas por los nitratos procedentes de fuentes agrarias [Order 77/1997, 27 May, of the Goverment of Aragón, to approve the Code of Good Agricultural Practice of the Autonomous Region of Aragón, and the appointment of areas as vulnerable zones to the water pollution of nitrates from agricultural sources]. Government of Aragon, Zaragoza, Spain 
Gómez-Alday JJ, Carrey R, Valiente N, Otero N, Soler A, Ayora C, Sanz D, Muñoz-Martín A, Castaño S, Recio C, Carnicero A, Cortijo A (2014) Denitrification in a hypersaline lake-aquifer system (Pétrola Basin, Central Spain): the role of recent organic matter and Cretaceous organic rich sediments. Sci Total Environ 497-498: 594-606. https://doi.org/10.1016/j.scitotenv.2014.07.129

Gonzales-Inca CA, Lepistö A, Huttula T (2016) Trend detection in waterquality and load time-series from agricultural catchments of Yläneenjoki and Pyhäjoki, SW Finland. Boreal Environ Res 21: 166-180

Hansen B, Thorling L, Dalgaard T, Erlandsen M (2011) Trend reversal of nitrate in Danish groundwater: a reflection of agricultural practices and nitrogen surpluses since 1950. Environ Sci Technol 45:228234. https://doi.org/10.1021/es102334u

Health Canada (2013) Guidelines for Canadian drinking water quality: guideline technical document — nitrate and nitrite. Health Canada, Ottawa

Hirsch RM, Slack JR, Smith RA (1982) Techniques of trend detection for monthly water quality data. Water Resour Res 18:107-121

Hirsch RM, Alexander RB, Smith RA (1991) Selection of methods for the detection and estimation of trends in water quality. Water Resour Res 27:803-813

Kronvang B, Andersen HE, Børgesen C, Dalgaard T, Larsen S, Bogestrand J, Blicher-Mathiasen G (2008) Effects of policy measures implemented in Denmark on nitrogen pollution of the aquatic environment. Environ Sci Pol 11:144-152. https://doi.org/10.1016/ j.envsci.2007.10.007

Kuhn NJ, Baumhauer R, Schütt B (2011) Managing the impact of climate change on the hydrology of the Gallocanta Basin, NE-Spain. J Environ Manag 92:275-283. https://doi.org/10.1016/j.jenvman. 2009.08.023

Kyllmar K, Mårtensson K, Johnsson H (2005) Model-based coefficient method for calculation of $\mathrm{N}$ leaching from agricultural fields applied to small catchments and the effects of leaching reducing measures. J Hydrol 304:343-354. https://doi.org/10.1016/j.jhydrol.2004.07.038

Liu A, Ming J, Ankumah RO (2005) Nitrate contamination in private wells in rural Alabama, United States. Sci Total Environ 346:112120. https://doi.org/10.1016/j.scitotenv.2004.11.019

López Bellido L, Betrán Aso J, Ramos Monreal Á, López Córcoles H, López Fuster P, Bermejo Corrales JL, Urbano Terron P, Piñeiro Andión J, Castro Insua J, Blázquez Rodríguez R, Ramos Mompó C, Pomares Garcia F, Quiñones Oliver A, Martínez Alcántara B, Primo-Millo E, Legaz Paredes F, Espada Carbó JL, GarcíaEscudero Domínguez E, García García C, Pérez Rodríguez J (2010) Guía Práctica de la Fertilización Racional de los Cultivos en España. Parte II. [Guidelines for rational fertilisation of crops in Spain, part II]. Ministerio Medio Ambiente y Medio Rural y Marino, Madrid

Lopez B, Baran N, Bourgine B (2015) An innovative procedure to assess multi-scale temporal trends in groundwater quality: example of the nitrate in the Seine-Normandy basin, France. J Hydrol 522:1-10. https://doi.org/10.1016/j.jhydrol.2014.12.002

Lord E, Shepherd M, Silgram M, Goodlass G, Gooday R, Anthony SJ, Davison P, Hodgkinson R (2007) Investigating the effectiveness of NVZ Action Programme measures: development of a strategy for England. DEFRA report NIT18, Department for Environment, Food and Rural Affairs, London

Macgregor CJ, Warren CR (2006) Adopting sustainable farm management practices within a nitrate vulnerable zone in Scotland: the view from the farm. Agric Ecosyst Environ 113:108-119. https://doi.org/ 10.1016/j.agee.2005.09.003

Macgregor CJ, Warren CR (2015) Evaluating the impacts of nitrate vulnerable zones on the environment and farmers' practices: a Scottish case study. Scottish Geogr J 132:1-20. https://doi.org/10.1080/ 14702541.2015 .1034760
Matzeu A, Secci R, Uras G (2017) Methodological approach to assessment of groundwater contamination risk in an agricultural area. Agric Water Manag 184:46-58. https://doi.org/10.1016/j.agwat. 2017.01.003

Merchán D, Auqué LF, Acero P, Gimeno MJ, Causapé J (2015) Environment geochemical processes controlling water salinization in an irrigated basin in Spain: identification of natural and anthropogenic in fluence. Sci Total Environ 502:330-343. https://doi.org/ 10.1016/j.scitotenv.2014.09.041

Musacchio A, Re V, Mas-pla J, Sacchi E (2019) EU nitrates directive, from theory to practice: environmental effectiveness and influence of regional governance on its performance. Ambio. https://doi.org/ 10.1007/s13280-019-01197-8

Neal C, Jarvie HP, Neal M, Hill L, Wickham H (2006) Nitrate concentrations in river waters of the upper Thames and its tributaries. Sci Total Environ 365:15-32. https://doi.org/10.1016/j.scitotenv.2006. 02.031

Peña-Gallardo M, Vicente-Serrano SM, Quiring S, Vallejo-Garcia A, Cooper JM (2019) Response of crop yield to different time-scales of drought in the United States: spatio-temporal patterns and climatic and environmental drivers. Agric For Meteorol 264:40-55. https://doi.org/10.1016/j.agrformet.2018.09.019

Quemada M, Baranski M, Nobel-de Lange MNJ et al (2013) Metaanalysis of strategies to control nitrate leaching in irrigated agricultural systems and their effects on crop yield. Agric Ecosyst Environ 174:1-10

Richard A, Casagrande M, Jeuffroy MH, David C (2018) An innovative method to assess suitability of nitrate directive measures for farm management. Land Use Policy 72:389-401. https://doi.org/10.1016/ j.landusepol.2017.12.059

Rojek A, Piskorek K, Kuczyñska A, Palak-mazur D (2017) Analysis of nitrate concentrations in groundwater of Poland (2004-2015), including areas vulnerable to pollution from agricultural sources. Prz Geol 65:2015-2018

Rotiroti M, Bonomi T, Sacchi E, McArthur JM, Stefania GA, Zanotti C, Taviani S, Patelli M, Nava V, Soler V, Fumagalli L, Leoni B (2019) The effects of irrigation on groundwater quality and quantity in a human-modified hydro-system: the Oglio River basin, Po plain, northern Italy. Sci Total Environ 672:342-356. https://doi.org/10. 1016/j.scitotenv.2019.03.427

Salmi T, Maatta A, Anttila P, Ruoho-Airola T, Amnell T (2002) Detecting trends of annual values of atmospheric pollutants by the MannKendall test and Sen's solpe estimates the excel template application MAKESENS. Finnish Meteorological Institute, Helsinki

Schütt B (1998) Reconstruction of Holocene paleoenvironments in the endorheic basin of Laguna de Gallocanta, central Spain by investigation of mineralogical and geochemical characters from lacustrine sediments. J Paleolimnol 20:217-234. https://doi.org/10.1023/A: 1007924000636

SIOSE (2018) Sistema de Información de Ocupación del Suelo de España [Information system of land use in Spain]. http://www.siose.es. Accessed 20 May 2019

Serio F, Miglietta PP, Lamastra L, Ficocelli S, Intini F, De Leo F, De Donno A (2018) Groundwater nitrate contamination and agricultural land use: a grey water footprint perspective in southern Apulia region (Italy). Sci Total Environ 645:1425-1431. https://doi.org/10. 1016/j.scitotenv.2018.07.241

Sohier C, Dautrebande S, Degré A (2009) Hydrological modelling of the EU Nitrates Directive Actions Programme: new developments in the Walloon Region (Belgium). In: Towards new methods to manage nitrate pollution within the Water Framework Directive. BRGM and ISONITRATE, pp 45-46. http://isonitrate.brgm.fr. Accessed May 2020

Sutton MA, Howard CM, Erisman JW, Billen G, Bleeker A, Grennfelt P, Van Grinsven H, Grizzetti B (2011) The European nitrogen 
Hydrogeol J

1002

1003

1004

1005

1006

1007

1008

1009

1010

1011

1012

1013

1014

1015

1016

1017

1018

1019

1020

1021

1022

1023

1024

1025

1026

1027

1028

1029

1057 assessment: sources, effects ad policy perspectives. Cambridge University Press, New York

Trifu MC, Ion MB, Daradici V (2013) Different methods for farmer's implication in the nitrate management at river basin scale. Int Multidiscip Sci GeoConference Surv Geol Min Ecol Manag SGEM, pp 101-108. https://doi.org/10.5593/SGEM2013/BC3/ S12.013

US Environmental Protection Agency (1996) Environmental indicators of water quality in the United States. EPA 841-R-96-002 30, US Environmental Protection Agency, Washington, DC

US Environmental Protection Agency (2007) Nitrates and nitrites: TEACH chemical summary. Assessment for children's health, toxicity and exposure. US Environmental Protection Agency, Washington, DC

Urresti-Estala B, Gavilán PJ, Pérez IV, Cantos FC (2016) Assessment of hydrochemical trends in the highly anthropised Guadalhorce River basin (southern Spain) in terms of compliance with the European groundwater directive for 2015. Environ Sci Pollut Res 23:15990 16005. https://doi.org/10.1007/s11356-016-6662-9

Valiente N, Carrey R, Otero N, Soler A, Sanz D, Muñoz-Martín A, Jirsa F, Wanek W, Gómez-Alday JJ (2018) A multi-isotopic approach to investigate the influence of land use on nitrate removal in a highly saline lake-aquifer system. Sci Total Environ 631-632:649-659. https://doi.org/10.1016/j.scitotenv.2018.03.059

Vero SE, Basu NB, Van Meter K, Richards KG (2018) Review: The environmental status and implications of the nitrate time lag in Europe and North America. Hydrogeol J 26:7-22. https://doi.org/ $10.1007 / \mathrm{s} 10040-017-1650-9$
Visser A, Broers HP, Van Der Grift B, Bierkens MFP (2007) Demonstrating trend reversal of groundwater quality in relation to time of recharge determined by $3 \mathrm{H} / 3 \mathrm{He}$. Ned Geogr Stud 148:3146. https://doi.org/10.1016/j.envpol.2007.01.027

Wang L, Stuart ME, Lewis MA, Ward RS, Skirvin D, Naden PS, Collins $\mathrm{AL}$, Ascott MJ (2016) The changing trend in nitrate concentrations in major aquifers due to historical nitrate loading from agricultural land across England and Wales from 1925 to 2150. Sci Total Environ 542:694-705. https://doi.org/10.1016/j.scitotenv.2015.10. 127

WHO (2011) WHO guidelines for drinking-water quality. WHO Chron 38:104-108. https://doi.org/10.1016/S1462-0758(00)00006-6

Wick K, Heumesser C, Schmid E (2012) Groundwater nitrate contamination: factors and indicators. J Environ Manag 111:178-186. https://doi.org/10.1016/j.jenvman.2012.06.030

Worrall F, Spencer E, Burt TP (2009) The effectiveness of nitrate vulnerable zones for limiting surface water nitrate concentrations. J Hydrol 370:21-28. https://doi.org/10.1016/j.jhydrol.2009.02.036

Yue S, Pilon P, Cavadias G (2002) Power of the Mann-Kendall and Spearman's rho tests for detecting monotonic trends in hydrological series. J Hydrol 259:254-271

Yue S, Pilon P (2004) A comparison of the power of the t test, MannKendall and bootstrap tests for trend detection. Hydrol Sci J 49:2138. https://doi.org/10.1623/hysj.49.1.21.53996

Zhang H, Yang R, Wang Y, Ye R (2019) The evaluation and prediction of agriculture-related nitrate contamination in groundwater in Chengdu Plain, southwestern China. Hydrogeol J 27:785-799
1030

1031

1032

1033

1034

1035

1036

1037

1038

1039

1040

1041

1042

1043

1044

1045

1046

1047

1048

1049

1050

1051

1052

1053

1054

1055

1056 


\section{AUTHOR'S PROOF!}

\section{AUTHOR QUERIES}

\section{AUTHOR PLEASE ANSWER ALL QUERIES.}

Q1. Ref. "Dubrovsky et al. 2010" is cited in the body but its bibliographic information is missing. Kindly provide its bibliographic information in the list.

Q2. Ref. "Di and Cameron 2002" is cited in the body but its bibliographic information is missing. Kindly provide its bibliographic information in the list.

Q3. Ref. "Basso et al. 2015" is cited in the body but its bibliographic information is missing. Kindly provide its bibliographic information in the list.

Q4. Ref. "Billen 2013" is cited in the body but its bibliographic information is missing. Kindly provide its bibliographic information in the list.

Q5. EEC 1991 is cited in the text but not listed in the ref list. Please supply the publishing details.

Q6. Ref. "BOA, 1997" is cited in the body but its bibliographic information is missing. Kindly provide its bibliographic information in the list.

Q7. Missing citation for Figure 2 was inserted here. Please check if appropriate. Otherwise, please provide citation for Figure 2. The order of main citations of figures/tables in the text must be sequential.

Q8. CHE 2019 is cited in the text but is not given in the ref list. Please supply the publishing details for this item.

Q9. Ref. "Mussachio et al. 2016" is cited in the body but its bibliographic information is missing. Kindly provide its bibliographic information in the list.

Q10. References [Arauzo et al, 2011, CHE (Confederación Hidrográfica del Ebro), 2018, European Commission, 2009, Gobierno de Aragón, 1997] were provided in the reference list; however, this was not mentioned or cited in the manuscript. As a rule, all references given in the list of references should be cited in the main body. Please provide its citation in the body text. 